\title{
SH2D1A Gene
}

National Cancer Institute

\section{Source}

National Cancer Institute. SH2D1A Gene. NCI Thesaurus. Code C75393.

This gene plays roles in proliferation, differentiation and activation of B and T-cells. 